\title{
Manifestations of Quran and Hadith in Qabus Nameh Prose
}

\section{Seyed Mojtaba Hoseini1*}

\section{Seyed Fayes Darkhosh2}

\author{
${ }^{1}$ Department of Persian Language and Literature, Faculty of Literature and \\ HumanitiesBushehr branch Islamic Azad University, Bushehr, Iran \\ 2 Department of Persian Language and Literature, Faculty of Literature and Humanities,Bushehr branch Islamic \\ Azad University Bushehr, Iran; *Corresponding author: Seyed Mojtaba Hoseini, E-mail: hoseinii.iau@gmail.com
}

Doi:10.5901/mjss.2015.v6n6s2p187

\section{Abstract}

Persian literature and language in the course of its long evaluation, with the birth of Islam, has been integrated by Quran and Hadith thinking and culture to demonstrate such a relation and effectiveness of literary works from these two valuable resources in different eras of Persian prose and there is no way to understand Quran courses and the innocents Hadith. The purpose of this article is to assess the different extents and procedures of Qabus Nameh effectiveness from Quran and Hadith recourses. The study of different parts of Qabus Nameh from this point of view shows that the effectiveness extents of the scholars and their different styles from these two important resources aren't identical. But it is clear that the knowledge of the writer on Quran and Hadith courses shows significantly such relation in the prose with two styles of visible and invisible effectiveness. In other words, Quotation and Allusion have high frequency among the different methods of the effectiveness such as insertion, solution, adaptation and so on.

Keywords: Qabus Nameh, Quran and Hadith effectiveness, Onsor al Meali, effectiveness style.

\section{Introduction}

Vast and rich culture of Islam, since the emergence of Persian poetry and prose, has been one of the main supports of Persian literature affected on it in different forms. The effectiveness from such rich culture due to the emergence of Islam is significantly evident. Persian writers not only have utilized Quran and Hadith ornaments in theology, but also ordered them. Onsor al Meali Kiekavus ibn Vushmgir has advised his son on secretarial principles and the qualifications of the writer as follows:

\begin{abstract}
"...and adorn your name with the metaphors and Quran verses and the prophet notices and if the name was a Persian name, do not write it in absolute Persian which is unsuitable, specially the old Persian (Dari) that is unknown and should not write it and it is better that you do it"'(Qubus name, 39th chapter). Using Quran and Hadith in Persian prose and poetry has indicated that the writer and the speaker have been familiar to Quran and Hadith teachings which are considered as an honor for them. The works affected by these two valuable resources (Quran and Hadith) have been gained the special religious and spiritual holiness and sanctity. Qubus Name, the valuable book, is a work adorned by Hadith and verses by its writer and therefore has a major impact on the readers.
\end{abstract}

\section{Literature Review}

\subsection{Onsor al Meali Keikavus and Qubus Name}

Amir Onsor al Meali Keikavus ibn Iskandar ibn Qubus ibn Vushmgir Ziari is one of the princes of Ziyarid dynasty governed in Gorgan and Gilan in fourth and fifth centuries in Iran. Keikavus is the writer of Nasihat name known Qabus Nameh. This book is written in 44 chapters. The main theme of this book is the advice of his son, Gilanshah. This valuable book contains the information and the experiences of the writer that has been written in the prose (in the middle prose or BEINABEIN), neither too Morsal nor too tecnical, known Nasihat name. This book has been considered one of the valuable works and didactic books in Persian prose. Due to its special value and didactic information and recalling Iranian ancient customs, the late professor Malek o-Shoara Bahar named this book as "Islamic civilization collection before Mongol". 


\subsection{Effectiveness and its Method from Quran and Hadith in Qabus name Prose}

The effectiveness from Quran and Hadith is sometimes obvious and sometimes hidden. The purpose of obvious and hidden effectiveness is that the writer or the poet has used the verses or the hadith with Arabic structures in his work or has stated the subject by using of the quotation from Arabic language or hadith; such as: And know that Supreme God has created nights for relaxation and sleep of the creatures and day for living and gaining livelihood means, as saying:

\section{"And caused the night a covering and caused the day for you to seek livelihood" (Al Naba, 9-10)}

But the obvious and hidden effectiveness is that the writer uses Quran and Hadith contents or considers his words on the basis of a verse or a narrative without mentioning to the references; such as: As though you are young, do not forget the Almighty and do not forget death because it is not safe for the young the old and every person is born finally will die. Such narrative has entered a kind of the precision allusion to so many verses and Hadith about the death. Therefore, it seems that the obvious and quotation effectiveness with a minimal familiarity to Quran and Hadith teachings has been perceived but in hidden and allusion effectiveness, only persons can perceive the concepts and approaches of the writers on Quran teachings that are familiar to Quran and Hadith teachings. So the use of Persian scholars from Quran and Hadith has different approaches that are not at same level due to effectiveness. Each scholar has used different approaches for these two resources including adaptation, allegory, pointing, quotation, insertion and solution. In Qabus nameh, the effectiveness from Quran and Hadith has the obvious aspect but the hidden or allusion aspect of Qabus nameh is also excellent. Such accurate effectiveness is not understood unless the reader should be familiar to the Quran and Hadith teachings.

\subsection{Some Cases of Effectiveness in Qabus nameh from Quran and Hadith}

\subsubsection{A: On Recognition of the Almighty}

Think about the gifts and bounties of God not on God. When a person is seeking a path in the deviated path, he takes steps in the deviated path, so that the Prophet said: "think on the gifts of God not on the nature of God" (Nahj al- Fasahe, 1170).

\subsubsection{B: On Creation of the World}

And know, oh the son, that the Almighty has created the world neither for his needs nor for the dazzle but for the justice. When it was adorned with wisdom, such adornment was certainly inevitable. Look at this world and see the ornaments of plants, animals, stews and nurtures; as He has said strongly: "and we created not the heavens and earth and what is between them both in sport") Dukhan, verse 38).

\subsubsection{C: On the Excess of Obedience and Ability}

Know, oh the son, that the Almighty has considered two duties for the rich and special persons including Hajj and Zakat. The Almighty bids that everyone has afforded should visit His house, not the persons that have not affordance. He has said mystics (dervishes): "and expend in the path of God and cast not yourselves with your own hands into perdition" (Baghare, verse 195).

But Zakat is a duty once a year for you and although the charity is not a duty but you can give and you should know that if the people give charity, they will always be in God safe so such safety is valued and useful. This narrative is an allusion to "Establish ye the prayer and give ye away the poor-rate and bow ye down" (Baghareh, verses 43 and 109). Also, Onsor al Meali has emphasized paying Zakat and the charity to his son in the same chapter of his book and has adorned his words with Quran and Hadith teachings; such as: "save your faith and you property by paying Zakat and the charity and keep away the calamity waves by blessing" (Hekmat, 146).

\subsubsection{D: On Recognition of the Parents' Right}

Beware, oh son. Do not abject the parents' suffers because the Almighty has mostly paid attention to the right of the parents. The Creators bids: " and commanded thy Lord hath that thou shall worship not anyone but Him; if either or both 
of them reach old age with thee, utter not unto them even so much as"fie" nor chide them and speak unto them a generous word" (Asra, verse 23).

\subsubsection{E: On the Sleep and Rest}

And know that Supreme God has created nights for relaxation and sleep of the creatures and day for living and gaining livelihood means, as saying: " and caused the night a covering and caused the day for you to seek livelihood"(Al Naba, verses 10 and 11).

\subsubsection{F: on Death}

Then it is obvious that all beings will die; therefore, everyone should believe in this field and attempt to gain his sustenance and trust. Ali ibn Abi Talib, AMIR AL MOMENIN- the greatness of God is his image- has noted briefly: "when I die I will born".

As though you are young, do not forget the Almighty and do not forget death because it is not safe for the young the old and every person is born finally will die. Such narrative from Qabus Nameh has entered a kind of the precision allusion to so many verses and Hadith about the death and its pomp including: " whever ye be, death will overtake you even if ye be in towers lofty"(Nesa, 78); "Veily similitude of Jesus with God is as the similitude of Adam. He created him out of dust then said He unto him BE and he became"(Al Imran, 58). Be aware, oh boy, that I am going soon and you will come very soon. Be aware that you should work, produce and foster in this mortal world until may reap their results in the immortal world that is better than the mortal world. You should search whatever He has created in this world. The mortal world is like a farm and whatever you foster, bad and good, you will reap finally. Everyone will reap what he has sown in his flourishing field, not in plantation, and such flourishing field is the immortal world. Any reader with little familiarity to Quran and Hadith teachings can realize the advice of Onser al Meali that are based on this Prophet Hadith: "the world is the farm of the hereafter"(Bahar al Anvar, Vol. 70, P. 148).

\subsubsection{G: On saving the Wealth and Blaming Lavishment}

But the lavishment is considered inauspicious and whatever God considers sinister it is inauspicious for the servants; such as: "and eat and drink ye and commit ye not excesses; Verily He loves not the extravagant" (Anam, verse 141) and (Aaraf, verse 31).

\subsubsection{H: On Holding the Trust}

If someone wants you to hold a trust, you should not accept because accepting the trust is accepting the calamity. Holding the trust has three aspects. You may deliver the trust to the owner well as the Almighty has said: "verily God doth command you to render back your trusts to their owners and when ye judge between men to judge with justice and how excellent is what God exhorteth you"(Nisa, verse 58). The Prophet (PBUH) has said: "the path of the generosity is not to accept the trusts of others but if you accept the trust you should hold it very well and deliver it to the lord well".

\subsubsection{I: On the Right of Children and the Right of Recognition}

Oh the son, if GOD grants you a child you first should name him with a good name that is one of the rights of children. Second you should take your child to the wise and kind nannies, take the tradition in due time, be happy with him as much as you can and teach him Quran to recite it. No doubt the content of these words is based on the wisdom of Ali ibn Abi Talib (399) on the mutual rights of the father and the child: "the right of child over his father is that his father names him with a good name and trains him very well and teaches him Quran".

\subsubsection{J: On the Needs and Complying}

And if someone needs something you should comply them and be his servant because we all are the servants of Allah and we all need Him and if we have no need to Allah, nobody worship HIM and if your prayers comply you should thank Him as the Almighty has said: "and when declared your Lord: if ye be grateful I will increase unto you and if ye be ungrateful, Verily my torment is indeed sever"(Ebrahim, verse 7). 


\subsubsection{K: On the Creation and Worship}

Every creature who uses the sustenance without justice should thank Provider that gives all of human beings the sustenance even inappreciative persons. When Provider is immune from any error and wrong, He helps the creature as He has mentioned in His book: "and in the heaven is your sustenance and what ye are promised with"(Al Ziriat, verse 22).

\subsubsection{L: On Satisfaction and Contentment}

If you want always not be sad, be contentment and not jealous until you have always good times because the basis of sadness is the jealousy. These words, undoubtedly, are referred allusively to this wisdom of Amir al Momenin that has said: "there is no treasure better than the satisfaction and contentment".

Also he has advised his son on the satisfaction and the contentment:

And know, my son, that people are affected goodly and badly by the effects of the celestial sphere; as my professor (God blessed him) stated that the man should always refract the effects of the celestial sphere and open his mouth and if it runs away from the celestial sphere he should gain with his neck and if it gives a morsel he should gain with his mouth. As God has mentioned: "He said: "O, Moses, Verily I have chosen thee above the people with My messages and with My words take then what I give thee and be thou of the grateful ones" (Al-Araf, verse 144). The effect of the celestial is not outside of them.

\subsubsection{M: On Commercial Training and Medicine}

Although the trade is not an industry or a craft that we can consider it as an absolute profession but if we look at the truth we can realize that its principles are similar to the principles of the tradesmen.

So if you want to know the honorable science and gain the commercial events, no knowledge is better than the medicine, from the previous religious knowledge, as the Prophet (PBUH) has stated: "the purpose of the permanent knowledge is Medicine" (Bahar al Anvar, Vo. 1, P. 220).

\subsubsection{N: On the Avoidance of Extremes in Everything}

Oh the son, do not overdo everything and consider it as an ominous action. Be moderate in all matters that the master of Shariat, the Prophet (PBUH) has stated: "the best matter is being moderate" (Nahj al Fesahe, 1481). Get used to speak slowly. If you were blamed due to speaking slowly, it is better than to harass due to speaking hastily.

\subsubsection{0: On the Wine- Drinking Ritual}

But I say nothing on the wine- drinking tradition and do not say to drink the wine because the youth do something and nobody can return to the young time and I cannot fit the young. But if you drink the wine, you should repent and request the Almighty to forgive you and being regretful because of your act until God lets you to repent. The repentance of Nasooh has bestowed His grace. No doubt, Onsor al Meali is derived the term "Nasooh repentance" from this verse: " 0 , YE WHO BELIVE, Turn ye unto God with a turning of sincere penitence happily your Lord will wipe out from you your sins"(Tahrim, verse 8).

\subsubsection{P: On the Punishment and Need}

Oh the son, do not punish the people for every sin. If everyone commits a sin, you can forgive him into your heart because he is a man and first sin was committed by man. No doubt, Onsor al Meali was been fully familiar to the story of Adam and Satan and his deceitfulness and has considered this verse of Quran: " and Adam acted not his Lord and got astray"(Taha, verse121).

\section{Conclusion}

The writers and poets have not used the verses and Hadith equally but all writers and poets have been influenced by these two valuable resources. No doubt, they have linked with Quran teachings and have confirmed their speeches and words with these teachings. Onsor al Meali Keikavus has selected two quotation and allusion styles from the 
effectiveness styles. No doubt, one of the effectiveness reasons of this text for the reader is the relationship of the writer with Quran teachings.

\section{References}

Ali i. A., (2000). Nahj al Balaghe, Persian- Arabic, Dashti translation, Mohammad, Qom, Amir al Momenin Research Institution, first publication.

Halabi, A., (2000). The effect of Quran and Hadith on Persian literature, Tehran: Asatir, first publication.

Holy Quran

Majlesi, M., (1982) Bahar al Anvar, Beirut, Alvafa, second publication,

Onsor al Meali, K. (1992), Qabus Nameh, edited by Yosefi, Gholam Hossein. Tehran: Scientific and Cultural Publications, sixth publication.

Payandeh, A. (1997), Nahj al Fasahe translation, Tehran, Javidan, second publication.

Shamisa, S. (1991) methodology of the prose, Payam Noor University. 